\title{
NPK: ESSENTIALS FOR SUSTAINABILITY
}

Fernando Galembeck ${ }^{\mathrm{a}, *,(\mathbb{C}, \text { André Galembeck }}{ }^{\mathrm{b}}$ and Leandra P. dos Santos ${ }^{\mathrm{a}}$

a Departamento de Físico-Química, Instituto de Química, Universidade Estadual de Campinas, 13083-861 Campinas - SP, Brasil

bDepartamento de Química Fundamental, Universidade Federal de Pernambuco, 50740-560 Recife - PE, Brasil

Recebido em 10/05/2019; aceito em 31/07/2019; publicado na web em 14/11/2019

\begin{abstract}
Human population growth and development has been largely dependent on non-renewable natural resources, which cannot be indefinitely sustained. Beyond, coal and other abundant resources cannot continue to be used at current rates due to their impact on the environment and climate. It is thus important to replace as much as possible the fossil fuels and scarce minerals as sources of energy and industrial raw materials. Biomass plays a key role in this scenario, since its availability depends on abundant but often misused resources: air, water, sunlight and land. The "oil shocks", the recognition of impending resource shortages, the global pollution and climate change led many governments and organizations to create roadmaps to Bioeconomy. This includes the growing use of plants and animals to produce energy and raw materials, but it cannot create food scarcity. Agriculture depends on the plant macronutrients $\mathrm{N}, \mathrm{P}$ and $\mathrm{K}$, and this article discusses their role in plant and animal growth, production and consumption, dependence on nonrenewable minerals and energy and perspectives for increasing their efficiency. Special attention is given to Brazilian agriculture that is heavily dependent on imported NPK, requiring strategic action and research.
\end{abstract}

Keywords: NPK; biomass; fertilizer; sustainability; agriculture.

\section{TOWARD A GREEN ECONOMY}

Following a few centuries of steady population growth and improvement in the living conditions, the human species currently faces two opposite scenarios. The first is the exhaustion of available resources ${ }^{1}$ leading to widespread misery with all its sequels. On the other hand, it is now possible to conceive that a new Golden Age is coming, when declining populations will live under previously unthinkable high standards. It is also possible that the two situations will coexist but segregated in different places or perhaps within the same geographic area, creating immense social and political tension.

The somber scenario is easily understood, considering the correlation between population growth and the production of nonrenewable resources, especially fossil fuels and mineral ores. Coal is an abundant resource, but it cannot continue to be exploited at current rates, due to its contribution to atmospheric $\mathrm{CO}_{2}$ concentration and the associated impact on the climate.

The opposite vision of a bright scenario is supported by fast growth of enabling technologies related to information and cognition, biotech and nanotechnology. Together, they are allowing the production of growing amounts of energy, raw materials ${ }^{2}$ and food, ${ }^{3}$ from renewable resources, ${ }^{4}$ while improving the quality of the environment and contributing to the dissemination of education, knowledge and other cultural goods.

Humankind can only reach a Golden Age if it concentrates efforts in creating or improving the required tools and conditions. Independent of political and social change, it is essential to enlarge product life-cycles, increasing recycling practices as well as shifting towards carbon-based raw materials derived from biomass. All these measures can decrease our current dependence on non-renewable or scarce raw materials and energy sources.

Of course, there are also possibilities like mining other planets and asteroids or doing elemental synthesis by controlled nuclear fusion, but these currently belong to the domain of science-fiction are not conceivable strategies for the next few decades. Moreover,

*e-mail: fernagal@unicamp.br time is pressing because the decadence of human species due to the exhaustion of resources and deterioration of the environment can start within two decades.

The previous arguments show the imperative of building a Green Economy, characterized by a steady production growth for generations to come and the protection of the environment. This can only be based on increased use of raw materials derived from the biomass that is the only massive, truly renewable source, added to increased dependence on alternative energy sources, including the biomass.

\section{FOOD, ENERGY AND RAW MATERIALS FROM BIOMASS}

Biomass was the main source of energy and industrial raw materials, until the advent of large-scale coal mining, soon followed by the exploitation of oil and gas, starting in early $19^{\text {th }}$ century and still growing. The latter was largely burned at the producing fields due to the limited availability of technology, investment and markets for its use, but it currently receives great attention among the fossil fuels because it has the lowest $\mathrm{CO}_{2}$ emissions per energy produced ratio.

Biomass supplied materials required for transportation, clothing, housing, tool parts and substrates for cultural goods, beyond food and energy. Materials derived from biomass are almost always classified as "soft matter", leaving plenty of room for the introduction of "hard" materials like metals, glass, amorphous or crystal silicon, uranium and others that greatly influenced human history. For instance, soft materials are not suitable for making engines operating at high temperatures, materials for high-rise buildings, large bridges, ships, or machinery.

The gradual replacement of biomass products with products derived from fossil fuels was supported by the now huge petrochemical industry that is currently the most visible part of the overall chemical sector. This acquired momentum with the invention of the large-scale thermoplastics in the 1930's and grew very fast until, it was first hit by the "oil shocks", in the 1970's.

The "oil shocks" were caused by conflicts among nations, not by oil scarcity. Indeed, at this time the oil industry was making great 
efforts to produce "single-cell protein" that was just yeast grown from oil, used as a carbon source. ${ }^{5}$ Nine "food from oil" plants in the USSR had capacities ranging between 50,000 and 240,000 tons/year and the Unesco Science Prize was awarded in 1976 to Alfred Champagnat, from the BP Lavera oil refinery in France, "for his findings on the low-cost mass production of new proteins from petroleum".

The "oil shocks" led industry and governments to look again at biomass as a source of energy and raw materials, giving up the then thriving food production from oil. Different countries approached the problem in different ways: large-scale replacement of gasoline with ethanol in $\mathrm{Brazil}^{6}$ (from sugarcane) and in the US (from corn), massive plantations of oil-producing plants like palm-tree and soybeans to make biodiesel in many countries, energy production from planted forest (Eucalyptus, pine and other tree species), research on fastgrowing grasses like bamboo or on Cannabis and other sources, including some animals. In Brazil, beef lard accounted for $c a$. 20\% of the fat input for making biodiesel. Brazil took a leading position in this process, ${ }^{7}$ thanks to the great improvements in its agricultural production that gave to this country a distinguished position as a food global supplier. ${ }^{8}$

Growing use of biomass ${ }^{9,10}$ for energy and raw-materials production increased from the later 1970s to 2007-8, when the "Food Crisis" led critics to accuse it to divert land and resources from food production. However, this crisis was largely due to financial speculation rather than to agricultural land scarcity, following the debacle of the American real-estate market, in 2008.

Following the "Food Crisis", several countries, the United Nations and other multilateral organizations designed studies and forecasts for Bioeconomy development in the next two decades. For instance, the Conclusion of the National Bioeconomy Blueprint shows the commitment of the Obama administration to Bioeconomy: "The Administration has made great strides in harnessing biological research innovations to address national challenges in health, energy, food, environment, and manufacturing via the commercial economy. But there is much more to be done. The Administration plans to explore additional creative ideas for promoting U.S. leadership in the bioeconomy...". ${ }^{11}$

Opposite to the criticism presented by some organizations, ${ }^{12}$ the Brazilian experience since the late 1970s proves that it is possible to increase food as well as fuel and raw materials outputs simultaneously, achieving impressive productivity gains thanks to new technology, management, responsible marketing practices and to implicit synergy that has always been exploited, but not often acknowledged. In this process, sugarcane revealed itself as a rich source of chemicals for many different industries and consumer uses. ${ }^{13,14}$ Most important, the positive contribution of fuels from agriculture to food sustainability has also been verified in Ethiopia, very recently. 3 It is now clear that the real quest is towards more efficient food production concurrent with the balanced utilization of biomass to produce energy and raw materials for the chemical and other industries. The potential of Brazilian biomass as a source of raw materials for pharmaceuticals, ${ }^{15}$ polymer materials ${ }^{16}$ and many other industrial products has been documented in this journal.

Agricultural expansion was always correlated to the deforestation, throughout the world. The great expansion in crop production in Brazil since 1970 coincided with a reduction in Amazonia and Cerrado areas. However, these processes are no longer correlated since the beginning of the 21 st century, when annual deforestation trends began to diverge from fluctuations in cropland area and cattle herd size. ${ }^{17}$ Unfortunately, this process was not accompanied by political and legal measures that could have prevented or alleviated the social tensions that developed concurrently. However, many authors concur in stating that that land use and its economic revenues can become compatible with social welfare and environmental stewardship in Brazil and other tropical countries. ${ }^{11,18}$

We must keep in mind that the global population in 2050 is estimated to raise from the current 7.2 billion to 9 billion people. On the other hand, there is room to expand planted areas while preserving the existing biomes. According to IBGE (Instituto Brasileiro de Geografia e Estatística) data ${ }^{19}$ Brazil has (2012 data) $65 \%$ of its territory currently covered by natural biomes (Amazonia - $85 \%$ of the original coverage, Cerrado - 51\%, Caatinga - 54\%, Pantanal - $85 \%$, Atlantic Forest - $12 \%$ and, Pampa - 46\%), mostly protected under the law - but suffers frequent ilegal aggressions. Only $7 \%$ are currently used for agriculture, while nearly $23 \%$ for pastures holding a low cattle population density. The country has more than 220 million cattle and nearly one cow/hectare. From this scenario, it is evident that the area currently used for crops + cattle can be optimized to become more efficient. Even if Brazil does not reach the 3.8 livestock/ ha density as in the Netherlands, a small reduction in the mismanaged pasture area will contribute large areas for planting, keeping all the other variables unchanged. Beyond, well-managed pasture areas show a great ability for soil carbon sequestration. ${ }^{20}$ The adoption of integrated crop-livestock-forestry systems and precision agriculture is already contributing to increase the efficiency of land use. Africa also has large areas of currently underused land.

\section{FERTILIZERS AND BIOMASS PRODUCTION}

Living beings are largely made from $\mathrm{C}, \mathrm{H}$ and $\mathrm{O}$ but they also depend on many other elements.

Plants cannot make DNA, RNA, enzymes, ATP and many other key components, in the absence of nitrogen and phosphorus. Potassium plays more subtle roles but its participation was already obvious to alchemists that analyzed plant ashes, finding large amounts of this element. It is now acknowledged as a vital regulator of plant responses and tolerance to abiotic stress ${ }^{21}$ for many reasons, including several physiological processes, such as stomatal regulation and photosynthesis. Plants are the main $\mathrm{K}$ source for humans, in whom $\mathrm{K}$ homeostasis keeps the level of plasma potassium within narrow limits, 3.5 to 5 millimol per liter. K deficiency or hypokalemia ${ }^{22}$ symptoms include muscle weakness, paralytic ileus, ECG abnormalities, decreased reflex response. Severe cases may lead to respiratory paralysis, alkalosis, and cardiac arrhythmia).

Thus, adequate supply of $\mathrm{N}, \mathrm{P}$ and $\mathrm{K}$ to plants is essential in any kind of agriculture, from large-scale contemporary agribusiness to organic or biodynamic agriculture. Plants use N, P and $\mathrm{K}$ in higher amounts than any other elements beyond $\mathrm{C}, \mathrm{H}$ and $\mathrm{O}$. For this reason, they are called macronutrients.

\section{N, P AND K DEMAND, SUPPLY, SOURCES AND ENVIRONMENTAL IMPACTS}

Following the FAO Bulletin, ${ }^{23}$ the world consumption of the three main fertilizer nutrients, nitrogen $(\mathrm{N})$, phosphorus expressed as phosphate $\left(\mathrm{P}_{2} \mathrm{O}_{5}\right)$, and potassium expressed as potash $\left(\mathrm{K}_{2} \mathrm{O}\right)$, was estimated to reach 186.67 million tons $\left(\mathrm{N}, \mathrm{P}_{2} \mathrm{O}_{5}\right.$ and $\left.\mathrm{K}_{2} \mathrm{O}\right)$ in 2016, up by 1.4 percent over 2015 consumption levels. The demand for $\mathrm{N}$, $\mathrm{P}_{2} \mathrm{O}_{5}$, and $\mathrm{K}_{2} \mathrm{O}$ was forecast to grow annually on average by $1.5,2.2$, and 2.4 percent respectively from 2015 to 2020 . In this period, the global capacity of the production of fertilizers, intermediates and raw materials was also expected to increase, and these projects have been verified so far, according to the most recent annual bulletins.

The FAO Bulletins provides data on the global and regional fertilizer supply / demand balance. The global balance is the difference between supply and total demand (including fertilizer demand + 
nonfertilizer demand). Regional balance is a medium-term indicator of potential changes in fertilizer nutrient demand and supply in the region. The installed supply capacity, operating rates and demand variations are carefully followed by organisms concerned with food safety, because they can have a strong effect on global food prices and availability.

Forecasts on the demand consider the cropped area and application rate of fertilizer, market feedback, estimates by industry associations, growth models, econometric models and expert advice. Other important factors are unforeseen: feedstock and/or raw material limitations, logistical problems, unscheduled shutdown in mining and transportation due to technical reasons, natural calamities (earthquake, mine flooding, etc.). These factors are not considered in the balance, but they may have an effect. Moreover, market turbulence may drive fertilizer price changes, as it was observed in the financial crisis in 2008. Shortly, the American real estate market had been growing steeply for a relatively long period but the basis for this growth was not solid. When this "bubble" burst, investors looked for other targets for their applications and found one in the global commodities market. Fertilizer, grain and other commodity steep price increases followed, triggering what was then called the "food crisis".

Data from industry shows a steady growth in the production and use of fertilizers (Figure 1), for the past thirty years. Nearly half of the consumption is from $\mathrm{N}$ fertilizers, followed by $\mathrm{P}$ and $\mathrm{K}$.

Three crops consume $45 \%$ of the $\mathrm{N}+\mathrm{P}+\mathrm{K}$ production: wheat, rice and corn. Oilseeds require 13\%, 16\% are used for fruits and vegetables, $4 \%$ for sugar crops and the same amount is used for cotton.

Brazil is among the five key fertilizer markets (Figure 2) and the Brazilian profile of $\mathrm{N}, \mathrm{P}$ and $\mathrm{K}$ consumption differs from the other main consumers. Some factors determining this difference will be discussed in the following sections, where each element will be discussed separately.

\section{Consumption trend per nutrient}

\section{Million tonnes nutrient}

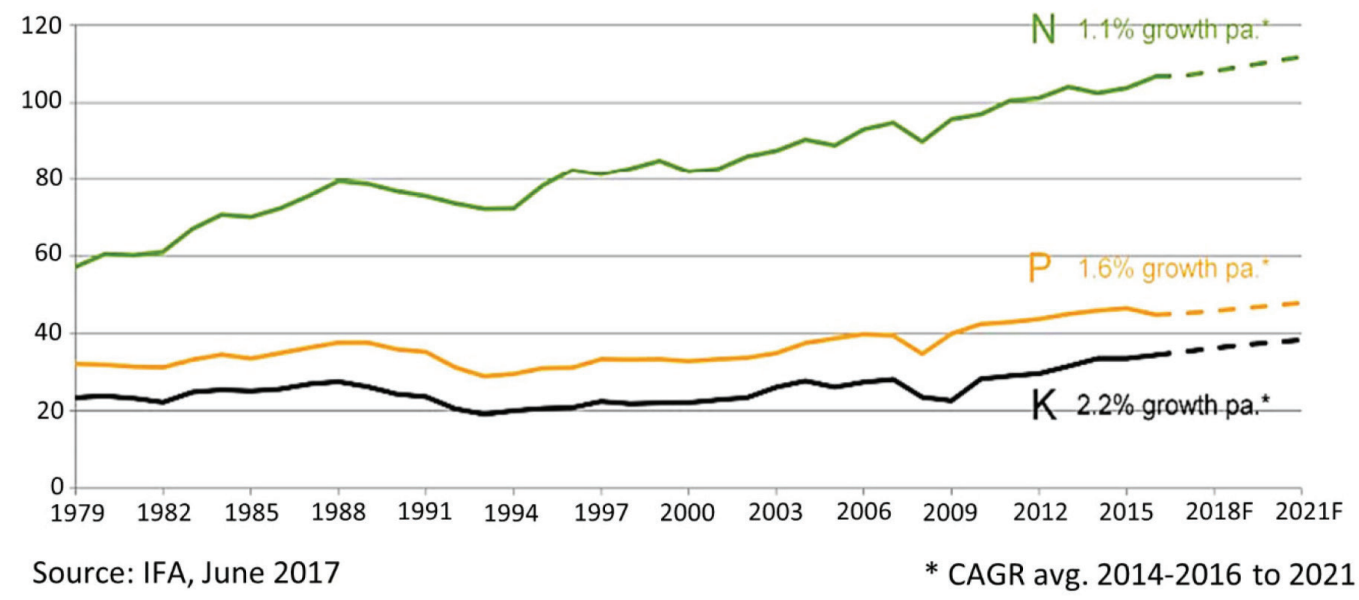

Figure 1. World annual NPK consumption and its projection to 2021. Reproduced from Reference 24

\section{Fertilizer consumption by region - 5 key markets}

\section{Million tons nutrient consumption}

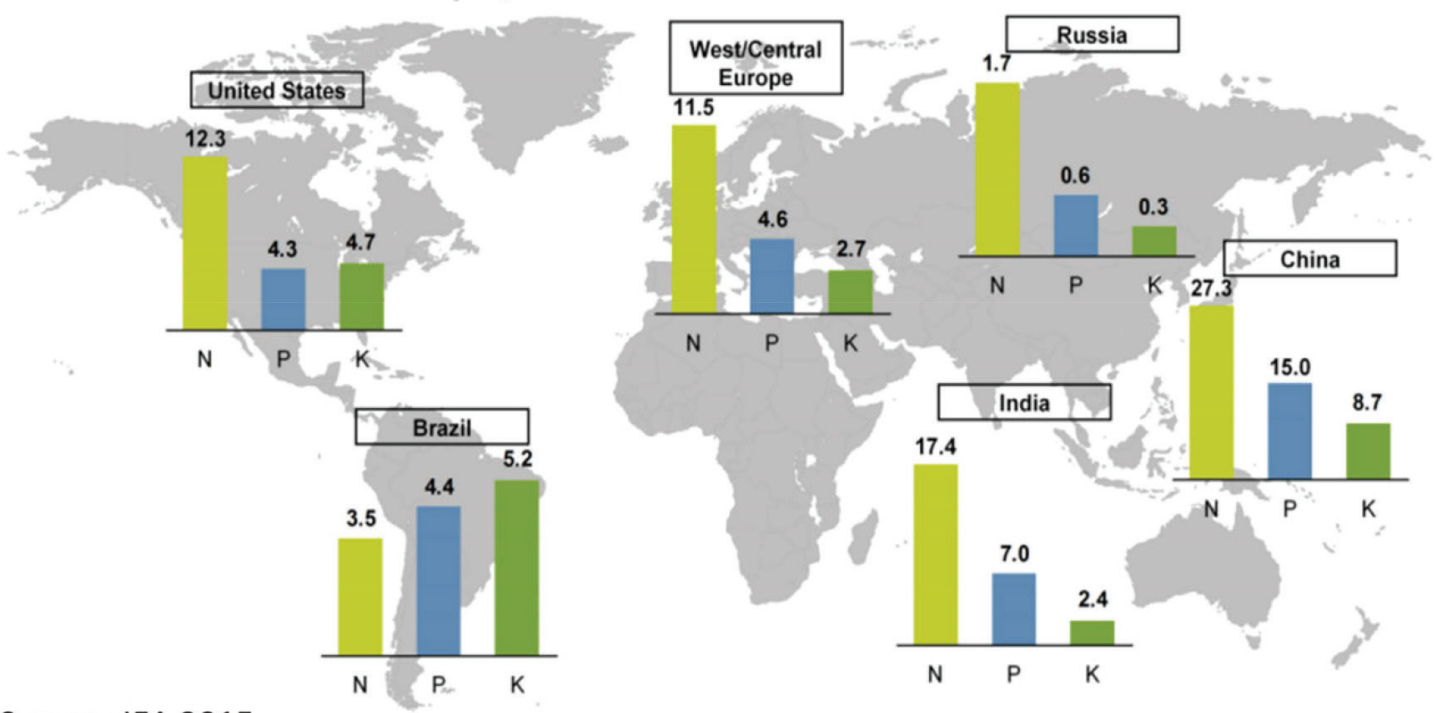

Source: IFA 2015

Figure 2. Variations on NPK consumption by region among different key markets. Reproduced from Reference 24 
The demand from various countries vary widely, due to differences in the crop pattern and size but also in the yield achieved per hectare, as shown in Figure 3. China shows the higher wheat and rice yields, while the US and Argentina are the leaders in maize and soybeans. Interestingly, all the countries showing higher rice yields/ha are in Asia.

The production and use of fertilizers are associated to many environmental issues. The impact of mining operations is well known and the phosphate tailings problem in Florida (US) is the most important case in the fertilizers area. Mining activities are geographically limited, and their impacts are not immediately felt by persons living at a distance from the mines. However, disasters like the recent iron ore tailing dam bursts in Mariana and Brumadinho show that the impacts of mining operations may be felt thousands of kilometers away from the mines. A widespread environmental impact of fertilizers is water eutrophication due to $\mathrm{P}$ and $\mathrm{N}$ runoffs, carried by rain towards internal and coastal waters, that will be discussed ahead. Less obvious are changes in soil texture that may create problems for agricultural practice, especially decreased water absorption capacity of the soil.

There is also evidence showing that sub-optimal crop nutrition tends to drive over-consumption of water. In a specific study, the optimized use of fertilizer led to a decrease in water requirement, from 600 to 380 liter per $\mathrm{kg}$ of wheat grain. ${ }^{24}$ If this is further verified, it may lead to a positive although indirect environmental impact of fertilizers by decreasing water consumption in agriculture. Since this activity uses up more water than human consumption and industrial activities together, reduced water consumption in water agriculture is highly desirable.

\section{Nitrogen}

$\mathrm{N}$ is the main component of the Earth atmosphere, but its abundance does not mean that it is easily available: every living species needs $\mathrm{N}$, but only a few can pick it up from the atmosphere, due to its chemical stability. It is interesting to compare the Gibbs energy or chemical potentials for the formation of various nitrogen simple compounds that is often positive, to the corresponding carbon compounds ${ }^{25}$ (Table 1). If this was not the case, $\mathrm{N}$ would spontaneously burn in the atmosphere. The formation of $\mathrm{N}$ compounds in the atmosphere may happen but only in a small scale as the result of lightning. This contributes to the overall $\mathrm{N}$ input in the crust, but other natural sources are more important, like the symbiotic microorganisms e.g. Leguminosae and the microbiota in some animal guts. For this reason, animal dejects have always been highly valued by farmers.

Nitrogen compounds are often water-soluble but there are a few insoluble compounds like struvite, $\left(\mathrm{NH}_{4}\right) \mathrm{MgPO}_{4} \cdot 6 \mathrm{H}_{2} \mathrm{O}$ that is found in bladder stones and forms scales in wastewater treatment equipment ${ }^{26}$ where from it can be reclaimed as a fertilizer. For this reason, mineral raw materials for $\mathrm{N}$ fertilizer production are not common, except for saltpeter that is the common designation for sodium and potassium nitrates. They are naturally formed by mineralization of bird dejects e.g. those living in seaside cliffs. In some places of the world (e.g. arid coastal areas in Chile and Peru), huge bird populations can grow, feeding on abundant fish. Their dejects cover the rocks and ground where they accumulate, in the absence of rain.

The nitrogenated compounds in the dejects (e.g. uric acid) are oxidized forming the more stable nitrates, that accumulate. In most parts of the world this cannot happen, because the dejects are washed out. For this reason, the saltpeter deposits in South America played an important strategic role in the European wars in the $19^{\text {th }}$ and early $20^{\text {th }}$ centuries, because they are a convenient source of nitric acid required by the production of gunpowder and explosives, as well as from soluble $\mathrm{N}$ compounds that are excellent fertilizers.

The problem of atmospheric nitrogen fixation, or its transformation

\section{Large variations in yields across regions}
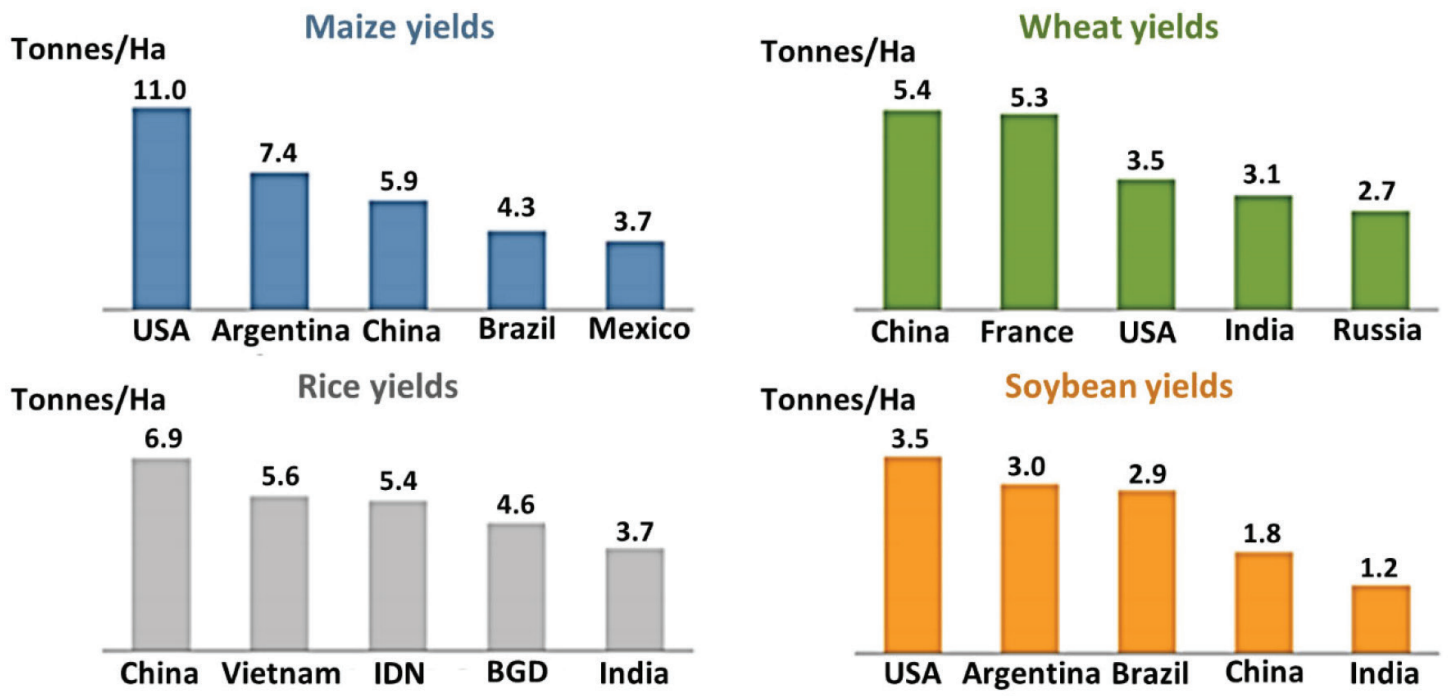

Source: FAOSTAT 2016

Figure 3. Differences on crop yields across regions and main producers. Reproduced from Reference 24

Table 1. Chemical potentials* of simple $\mathrm{N}$ and $\mathrm{C}$ compounds, under standard conditions

\begin{tabular}{ccccccccc}
\hline Compound & $\mathrm{CH}_{4}$ & $\mathrm{C}_{2} \mathrm{H}_{6}$ & $\mathrm{CO}$ & $\mathrm{CO}_{2}$ & $\mathrm{NH}_{3}$ & $\mathrm{~N}_{2} \mathrm{H}_{4}$ & $\mathrm{NO}$ & $\mathrm{NO}_{2}$ \\
\hline$\mu\left(\mathrm{kJ} \mathrm{mol}^{-1}\right)$ & -50.53 & -32.0 & -137.17 & -394.37 & -16.45 & 149.34 & 87.59 & 52.31 \\
\hline
\end{tabular}

*Source: reference 25 . 
in soluble compounds that can be absorbed by plants changed with the invention of the Haber-Bosch ammonia synthesis.

Haber-Bosch process has been the main source of nitrogen compounds for the agriculture and industry, for the past hundred years. There is currently no sign that it will lose its role as the main single provider of proteins for feeding the humankind and its importance may be assessed by considering that it uses up ca. $1 \%$ of the total energy produced or converted by human activities. This chemical process is an excellent demonstration of the power of technology to dismiss negative forecasts and it has been acknowledged as a major success against Malthus views, presented in the $19^{\text {th }}$ century. A significant fraction of the ammonia produced is converted to urea, a stable solid that can be easily transported, stored, supplied to the final user, either pure or mixed with $\mathrm{P}$ and $\mathrm{K}$ compounds. Urea is also used directly mixed within cattle feed, as a source of nitrogen. This is a shorter path between the Haber-Bosch plants and meat for human consumption, bypassing the intermediate grass, soybean and corn-based cattle feeds.

There is now a strong association between ammonia production and oil/gas availability, because the Haber-Bosch synthesis requires hydrogen, whose main current sources are the oil and gas crackers. For this very reason, the first large ammonia plant in Brazil was built in Cubatão, adjacent to the first large-scale oil refinery in this country. This is an important point to keep in mind, while discussing oil replacement by biomass: making chemicals and the derived materials from cellulose, lignin and other plant materials often requires hydrogen and biomass is not a ready source of hydrogen, comparable to oil and natural gas.

The larger global producer of nitrogen fertilizers is Yara International ASA, headquartered in Oslo that was initially established as Norsk Hydro in 1905. Hydrogen was then produced mainly by water electrolysis, an area in which Norsk Hydro was prominent, decades before Norway became an important oil producing country. Today, Yara is partnering with the French Engie company (formerly GDF Suez) to make hydrogen from sunlight and seawater in the Pilbara, Western Australia ammonia plant.

\section{Potassium}

The status of $\mathrm{K}$ as a chemical element was not known when Lavoisier listed the elements in $1789 .{ }^{27}$ Minerals known as potash were then known for a long time and their applications were the production of glass, bleach, soap or gunpowder, as potassium nitrate (also obtained from saltpeter). Potassium soaps from animal fats and vegetable oils were appreciated because of their higher solubility and softer texture, and they are known as soft soaps. In Brazil, "sabão de cinzas" was often made as a domestic product. In 1840, Justus Liebig ${ }^{28}$ discovered that potassium is a necessary element for plants, but it is often lacking in agricultural soils, creating a high demand for this element. This was initially answered by using ash from trees, but in 1868 mineral deposits containing potassium chloride were discovered near Staßfurt, Germany. The production of potassium fertilizers then began at an industrial scale and this city became the center of the German $\mathrm{K}$ fertilizer industry, with recoverable reserves of up to 0.8 tons, expressed as $\mathrm{K}_{2} \mathrm{O}$.

Other large potash deposits were discovered in Saskatchewan, Canada, and by the 1960 s this country became the dominant producer, with recoverable reserves amounting to nearly 10 billion tons. These deposits were discovered during World War II, and mining began in the 1960s. They are exploited by Potash Corp that is one of the world's leading producers, ca. 8 million tons in 2013. Other important deposits are in the Perm Territory, (Urals, Russia), Soligorsk in Belarus, New Mexico in the US and Yorkshire, in the UK, which has a large potential. The reserves in the Urals amount to 210 billion tons, they are owned by Uralkali that produces $20 \%$ of the world potassium production (9.12 million tons of $\mathrm{KCl}$, in 2012) ${ }^{29}$ and employed ca. 11,000 people in its main production unit, in 2018. ${ }^{30}$

Current recoverable reserves are concentrated in Canada (38.7\%), Russia (31,4\%), Western Europe (18.5\%) and India (10.8\%). It is mined from the ground ( $80 \%)$, evaporated from salt lakes and the Dead Sea (12\%) or by underground dissolution of salt deposits $(8 \%){ }^{31}$

The main chemical constituents in potash are sylvite $(\mathrm{KCl})$, carnallite $\left(\mathrm{KCl} \cdot \mathrm{MgCl}_{2} \cdot 6\left(\mathrm{H}_{2} \mathrm{O}\right)\right)$, kainite $\left(\mathrm{MgSO}_{4} \cdot \mathrm{KCl} \cdot 3 \mathrm{H}_{2} \mathrm{O}\right)$ and langbeinite $\left(\mathrm{MgSO}_{4} \cdot \mathrm{K}_{2} \mathrm{SO}_{4}\right)$ are highly soluble in water, limiting the deposit formation to two types, only: underground deposits naturally protected from underground waters and the salt beds or lakes in arid regions in the world. Potash mineral deposits were formed in different periods: the Canadian deposits formed in 370 million years ago, in the Upper Devonian while the Russian deposits were formed during an extended period, from 275 to 400 million years. Deposits in the North-East coast and in African west coast are from the Cretaceous (120 million years ago) and more modern deposits represented by salt lakes are in Chile, China, Israel, Jordan and in the US. In Brazil, there is only one underground producing area in Sergipe, but alkaline rocks found in many places throughout the country contain large amounts of potassium.

Potassium from complex mineral mixtures is extracted using more or less involved separation processes, halurgy and flotation. The flowsheet of the process used with carnallitite ore, ${ }^{32}$ that contains only $7.3 \% \mathrm{~K}$ is shown in Figure 4. Two main products of this process are $\mathrm{NaCl}$ and $\mathrm{KCl}$.

Potassium also occurs in common rock-forming minerals, like orthoclase (potassium feldspar). Granite contains 5\% potassium, well above the average content of this element on Earth crust. This is one of the bases for the use of powdered rock in organic agriculture.

\section{Phosphate}

In the living beings, biomass and fertilizers context, $\mathrm{P}$ is almost exclusively represented by phosphate that is quite different from the other two plant macronutrients in one aspect: most metal phosphates are insoluble. They can thus occur in many forms and places but the main source used for fertilizers is hydroxyapatite, a member of the apatite group, $\mathrm{Ca}_{5}\left(\mathrm{PO}_{4}\right)_{3}(\mathrm{~F}, \mathrm{Cl}, \mathrm{OH})$ that may contain significant amounts of halide substituting for hydroxide ions. Apatites are highly insoluble and they are thus found in sedimentary rock formations as well as in deposits formed directly from the magma.

Other phosphates are also sources of important elements: rareearths (monazite, $\mathrm{La}, \mathrm{Y}, \mathrm{Nd}, \mathrm{Sm}, \mathrm{Gd}, \mathrm{Ce}$, Th phosphates; xenotime $\mathrm{Y}\left(\mathrm{PO}_{4}\right)$ ), lead (hinsdalite, $\mathrm{PbAl}_{3}\left(\mathrm{PO}_{4}\right)\left(\mathrm{SO}_{4}\right)(\mathrm{OH})_{6} ; \mathrm{Pb}_{5}\left(\mathrm{PO}_{4}\right)_{3} \mathrm{Cl}$, pyromorphite), uranium (autunite, $\mathrm{Ca}\left(\mathrm{UO}_{2}\right)_{2}\left(\mathrm{PO}_{4}\right)_{2} \cdot 10-12 \mathrm{H}_{2} \mathrm{O}$ and many others). Others are semi-precious stones (lazulite, $(\mathrm{Mg}, \mathrm{Fe})$ $\mathrm{Al}_{2}\left(\mathrm{PO}_{4}\right)_{2}(\mathrm{OH})_{2}$ and turquoise, $\mathrm{CuAl}_{6}\left(\mathrm{PO}_{4}\right)_{4}(\mathrm{OH})_{8} \cdot 5 \mathrm{H}_{2} \mathrm{O}$.

Moreover, due to the chemical similarity between phosphate and arsenate, there are also the complex mineral series, like the arseniosiderite-mitridate series, $\left(\mathrm{Ca}_{2}\left(\mathrm{Fe}^{3+}\right)_{3}\left[(\mathrm{O})_{2} \mid\left(\mathrm{AsO}_{4}\right)_{3}\right] \cdot 3 \mathrm{H}_{2} \mathrm{O}--\right.$ $\left.\mathrm{Ca}_{2}\left(\mathrm{Fe}^{3+}\right)_{3}\left[(\mathrm{O})_{2} \mid\left(\mathrm{PO}_{4}\right)_{3}\right] \cdot 3 \mathrm{H}_{2} \mathrm{O}\right)$ and the arseniosiderite-robertsite series $\left(\mathrm{Ca}_{2}\left(\mathrm{Fe}^{3+}\right)_{3}\left[(\mathrm{O})_{2} \mid\left(\mathrm{AsO}_{4}\right)_{3}\right] \cdot 3 \mathrm{H}_{2} \mathrm{O}-\mathrm{Ca}_{3}\left(\mathrm{Mn}^{3+}\right)_{4}\left[(\mathrm{OH})_{3} \mid\left(\mathrm{PO}_{4}\right)_{2}\right]_{2} \cdot 3 \mathrm{H}_{2} \mathrm{O}\right)$ that contain phosphate but accompanied by the toxic arsenate ions.

Given this diversity, whenever a phosphate ore as a raw material is considered for making fertilizers, attention should be paid to the accompanying elements that is some cases are highly undesirable. The same problem arises while using dejects and waste to make organic fertilizers: if these have been in contact with toxic elements, they will likely trap them. This happens within mismanaged garbage dumps ("lixões") where food leftovers contact used car batteries, for instance, creating the opportunity for lead phosphate formation. 


\section{Processing}

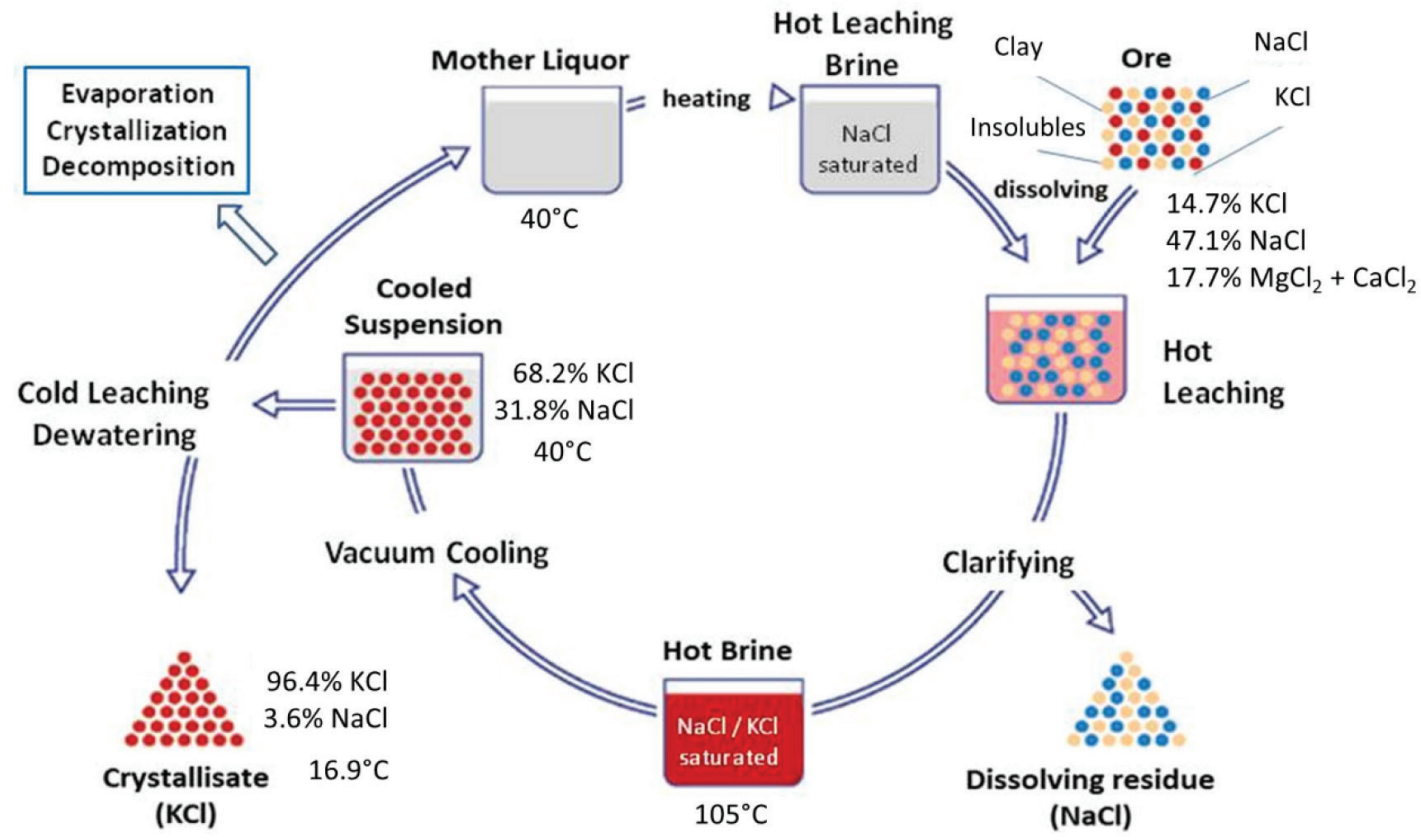

Figure 4. Flowsheet of hot crystallization process of carnallitite ore from Bamnet Narong Deposit. Reproduced from reference 32

\section{CURRENT RESERVES}

Nitrogen extraction from the air will likely continue to be unhindered, for centuries or millennia, provided the energy required to do $\mathrm{N}$ fixation through the Haber-Bosch process is available or alternative chemical or biological $\mathrm{N}$ fixation processes are discovered and developed. It is important to take into account the mechanisms implied in fertilizer nitrogen transformation and uptake by plants that are part of the global $\mathrm{N}$ cycle. ${ }^{33}$

$\mathrm{K}$ is also abundant: the global recoverable reserves warrant fertilizer production at the current rates for thousands of years, as presented in the Potassium section of this article. Beyond, there is plenty of this element in the seawater and in minerals that are not currently considered as economic sources of this element. However, the concentration of potassium ores in a few places in the world leads some countries with large agricultural production to depend on imports, as in the case of Brazil and China.

On the other hand, $\mathrm{P}$ availability has been a matter of concern and the literature contains many references to its scarcity, in a near future. This is a matter of current debate, triggered by resource estimates published by IFDC ${ }^{34}$ that were criticized in the literature. ${ }^{35}$ The center of the criticism in the reported increase in global phosohate rock (PR) reverse, from $16000 \mathrm{Mt}$ in 2010 to $65000 \mathrm{Mt}$ in 2011 and further to $67000 \mathrm{Mt}$ PR in 2014. This 4-fold increase derives mainly from the increased Moroccan reserves, from $5700 \mathrm{Mt}$ PR as reported by USGS, to $51000 \mathrm{Mt}$ PR, reported as "upgraded concentrate". The same report increased global resources from $163000 \mathrm{Mt}$ PR reported in the literature in 1989 to $290000 \mathrm{Mt} \mathrm{PR}$

Edixhoven et al. stated that the data on which the IFDC statements were based "do not appear to warrant such a conclusion. Further research is required as to the quantity of PR deposits and their viability for future extraction, using uniform and transparent classification terminology."

However, the critics were also criticized ${ }^{36}$ by Scholz et al., who reached an estimated $57.5 \mathrm{Gt}$ of phosphate rock reserves, not far from the IFDC $64 \mathrm{Gt}$ estimate. The main issue is the assessment of Moroccan reserves that currently represent a sizable fraction of the global estimate. This dispute originates ultimately from differences in terminology and in methodology used by different authors.

Since $\mathrm{P}$ fertilizers are currently consumed at the rate of ca. $0.05 \mathrm{Gt}$ a year, reserves in the range of $60 \mathrm{Gt}$ can sustain the current exploitation rate for more than one-thousand years. It remains to be seen which fraction of these resources will be actually converted into reserves. On the other hand, there is a heavy concentration of the current reserves in Morocco (Table 2) that poses another problem to large $\mathrm{P}$ importers that is the dependence on a single supplier.

\section{BRAZILIAN DEPENDENCE ON IMPORTED SUPPLIES}

Brazil is strongly dependent on imported fertilizers, as well as Latin America and the Caribbean that show a negative demand/supply balance for N, P and K, shown in Figure 5. This country is the fourth main consumer of fertilizers in the world and nearly $74 \%$ are imported (N-75\%; P - 51\%; K - 91\%). From 2007 to 2017, the NPK imports increased by more than $100 \%$, reaching USD 2.75 billion in 2017 . The evolution of the $\mathrm{K}_{2} \mathrm{O}$ balance in Latin America, in the 2015-2020 period, is shown in Table 3: The production capacity is stagnant, and the actual supply capability increases less than the demand, leading to an expected negative balance in excess of 6.5 million tons, for the region. The situation is aggravated by estimated $50 \%$ losses of the nutrients used by farmers: highly soluble $\mathrm{N}$ and $\mathrm{K}$ compounds are leached by rain and $\mathrm{P}$ is sequestered in the iron (III) and aluminumrich soils.

Nitrogen imports could decrease if new ammonia and urea plants were built in the country, benefitting from the increased oil and gas production. However, $\mathrm{P}$ and $\mathrm{K}$ depend on the availability of mineral ores.

Figure 5 also shows that Africa has large positive balances in $\mathrm{N}$ and $\mathrm{P}$, which is very important because this continent can potentially undergo a large growth in its agricultural production output. For this 
Table 2. IFDC world phosphate reserve and resource estimate. Reproduced from reference 34

\begin{tabular}{|c|c|c|}
\hline Country & $\begin{array}{l}\text { IFDC reserves } \\
\text { (Product) } / \mathrm{mmt}\end{array}$ & IFDC resources $/ \mathrm{mm}$ \\
\hline United States & 1800 & 49000 \\
\hline Australia & 82 & 3500 \\
\hline Brazil & 400 & 2800 \\
\hline Canada & 5 & 130 \\
\hline China & 3700 & 16800 \\
\hline Egypt & 51 & 3400 \\
\hline Israel & 220 & 1600 \\
\hline Jordan & 900 & 1800 \\
\hline Morocco & 51000 & $170000^{c}$ \\
\hline Russia & 500 & 4300 \\
\hline Senegal & 50 & 250 \\
\hline South Africa & 230 & 7700 \\
\hline Syria & 250 & 2000 \\
\hline Togo & 34 & 1000 \\
\hline Tunisia & 85 & 1200 \\
\hline Other Countries & $600^{\mathrm{d}}$ & $22000^{\mathrm{e}}$ \\
\hline World total (rounded) & 60000 & 290000 \\
\hline
\end{tabular}

${ }^{a}$ Reserves as usable or marketable product. ${ }^{b}$ Resources as unprocessed phosphate rock of varying grades or concentrate. Including hypothetical resources based on the area limits of the deposits. Morocco resources may be about $340000 \mathrm{mmt}$. 'Includes data from Algeria, Finland, Peru and Saudi Arabia (Al-Jalamid). 'Includes data from Algeria, Angola, Finlad, Kasakhstan, Peru and Saudi Arabia.

reason, the Brazilian dependence on imports may leave this country in a strategically poor condition, if agriculture develops in Africa in the next few decades, analogous to what happened in Brazil since the 1970 s.

The negative NPK balance in Brazil is compensated by the large surpluses in the trade balance of grains, paper and cellulose, fruits and other agricultural products but it strongly suggests that any strategic plan for strengthening Brazilian capacity of food, energy and raw materials from biomass should include measures to decrease this country dependence on fertilizer imports - by increasing the local production, by developing alternative nutrient sources and by curbing fertilizer waste.

\section{STRATEGIES FOR GLOBAL SUSTAINABILITY AND FOR DECREASING THE BRAZILIAN EXTERNAL DEPENDENCE: LOWER CONSUMPTION, RECLAIMING, RECYCLING}

Within the NPK plant macronutrients, $\mathrm{N}$ is practically inexhaustible but at the cost of large energy inputs, while $\mathrm{P}$ and $\mathrm{K}$ are non-renewable resources that should be conserved within circular production, consumption and recovery cycles. A positive NPK world balance is projected for the next few years, (Table 4) and it should remain positive for a few decades, but forecasts are not made for longer periods.

$\mathrm{P}$ deserves greater attention, because of its restricted availability that led the European Union to include phosphate rock within the list of Critical Raw Materials, in 2014. ${ }^{37}$ and of the environmental problems created by ore processing and waste disposal. The later often leads to water bed eutrophication with the ensuing air and water pollution. Thus, phosphate recovery is an important research topic, ${ }^{38}$ including many different approaches. Efforts to extract phosphate ions from effluents have now contributed sophisticated procedures that benefit from recent developments in materials chemistry and nanotechnology, ${ }^{39}$ including derivatized nanoparticles, nanohybrids and separation membranes. Phosphate recovery from struvite scales in wastewater treatment plants ${ }^{20}$ is especially attractive, since it contains nitrogen and magnesium, beyond phosphate. Non-fertilizer calcium phosphates are also produced by the companies that produce $\mathrm{P}$ fertilizers and they are sold as a complement in human and animal nutrition, ending up in sewage and wastes. Any human and animal waste should thus be treated, eliminating this important source of water and air pollution while reusing waste phosphate as a fertilizer, thus increasing its life cycle. Moreover, phosphate absorbed by edible plants may re-enter this cycle to be used many times.

In Brazil and other humid tropical places, agricultural soils are strongly weathered due to leaching by the intense $\mathrm{CO}_{2}$ - rich rain. Moreover, the cation exchange capacity (cec) of these soils is low, due to the prevalence of kaolin over bentonite and other clays with high cec. The soils are thus depleted from cations and acidic, but they contain $\mathrm{Fe}^{3+}$ and $\mathrm{Al}^{3+-}$ aluminum oxides and hydroxides that are strong

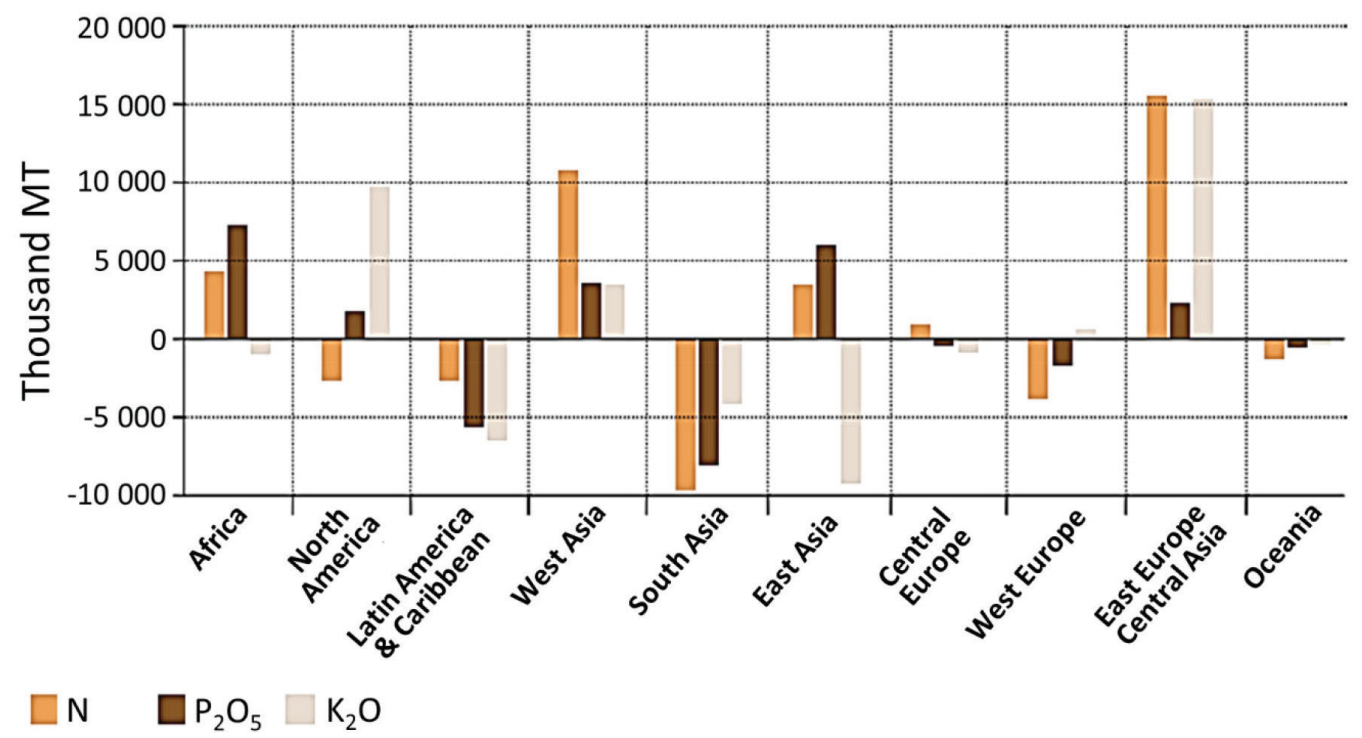

Figure 5. Anticipated nutrient balances in 2020. Reproduced from reference 23 
Table 3. World and regional potash supply, demand and balance 2015-2020 (thousand tonnes $\mathrm{K}_{2} \mathrm{O}$ ). Reproduced from reference 23

\begin{tabular}{|c|c|c|c|c|c|c|}
\hline \multicolumn{7}{|c|}{ Latin American and Caribbean } \\
\hline Year & 2015 & 2016 & 2017 & 2018 & 2019 & 2020 \\
\hline $\mathrm{K}_{2} \mathrm{O}$ capacity & 2125 & 2125 & 2125 & 2125 & 2125 & 2125 \\
\hline $\mathrm{K}_{2} \mathrm{O}$ supply capacity & 1704 & 1756 & 1756 & 1842 & 1842 & 1842 \\
\hline Non-fertilizer $\mathrm{K}_{2} \mathrm{O}$ demand & 600 & 600 & 600 & 600 & 600 & 600 \\
\hline $\mathrm{K}_{2} \mathrm{O}$ available for fertilizer & 1104 & 1156 & 1156 & 1242 & 1242 & 1242 \\
\hline $\mathrm{K}_{2} \mathrm{O}$ fertilizer demand & 6733 & 6917 & 7048 & 7178 & 7510 & 7841 \\
\hline Potential $\mathrm{K}_{2} \mathrm{O}$ balance & -5630 & -5761 & -5892 & -5935 & -6267 & -6599 \\
\hline
\end{tabular}

Table 4. Potential world balance of nitrogen, phosphate, potash for the years 2015 to 2020 , expressed in thousand tonnes. Reproduced from reference 23

\begin{tabular}{lcccccc}
\hline Year & 2015 & 2016 & 2017 & 2018 & 2019 & 2020 \\
Nitrogen $(\mathrm{N})$ & 11130 & 12769 & 17487 & 17404 & 15792 & 14477 \\
Phosphate $\left(\mathrm{P}_{2} \mathrm{O}_{5}\right)\left(\mathrm{H}_{3} \mathrm{PO}_{4}\right.$ - based) & 4105 & 3984 & 3769 & 4193 & 4349 & 4142 \\
Potash $\left(\mathrm{K}_{2} \mathrm{O}\right)$ & 5107 & 4100 & 5233 & 6701 & 7200 & 6617 \\
Total $\left(\mathrm{N}+\mathrm{P}_{2} \mathrm{O}_{5}+\mathrm{K}_{2} \mathrm{O}\right)$ & 20342 & 20853 & 26490 & 28298 & 27341 & 25236 \\
\hline
\end{tabular}

absorbents of phosphate ions, decreasing their availability. There have been estimates of losses of up to $50 \%$ of the total amount of phosphate added to some areas, due to sequestration in the soil. Management practices conducive to an increase in the amount of organic matter in the soil may counter phosphate sequestration, either by creating reducing environments for $\mathrm{Fe}^{3+}$ ions, by creating competing sites for phosphate binding and by favoring the proliferation of Mycorrhiza that bind and translocate nutrients in the soil. There is public complaint in this country and throughout the world, about excessive plant growth in water reservoirs and dams. Much can be done to improve the water quality in these reservoirs making them more suitable for various purposes, by doing simple housekeeping: collecting the mature and the dead plants with all the nutrients that they incorporated and processing them using techniques adequate to large amounts of residual biomass. This includes techniques that have been introduced in recent years, to handle residues from industrial agriculture like in the current ethanol-sugar-electricity plants based on sugar cane or in large-scale poultry, pig and cattle production.

Potassium compounds are highly soluble and losses by leaching were already mentioned. It is not easy to devise systems to recover potassium from effluents and agricultural run-offs but the intrinsic stability and vigor of the Amazon forest shows the effectiveness of trees to keep nutrients enclosed within a nutrient-deficient area, supplying the new plants with minerals released by decaying dead plants. This is one of the reasons why it is so important to maintain trees and other vegetation lining rivers and separating them from agricultural areas, thus preventing valuable fertilizer from leaching out of the fields and into the water courses.

Moreover, strategies are needed for using the potassium from the existing minerals that are not usually considered as economic sources of this element. There are impressive experimental results on this subject, for instance: "In a 3rd experiment employing Eucalyptus trees it was shown that basalt powder alone gave greater gains than did N-P-K fertilizers." ${ }^{" 0}$ Considering the uses of Eucalyptus as a raw material for cellulose production or as a fuel, it is clear that the rock potassium pumped from the ground by the trees can be recovered from wastewaters or ashes and further used in other crops. A comprehensive tutorial review of this subject was recently published, with comprehensive literature coverage and pointing to problems and limitations of the techniques used and making implicit suggestions for research. ${ }^{41}$ Soon later, a hydrothermal treatment of granite yielded very positive conclusions: "Preliminary green-chemistry considerations together with the properties of the hydrothermal material indicate a feasible path for introducing a green-chemistry paradigm in potassium fertilization. Raw materials... are affordable, globally available and compatible with the total environment. Mild processing conditions permit one to envision a relatively easy implementation pathway to industrial scale and may benefit from engineering knowledge available from analogous hydrothermal processes already operating at scale." ${ }^{42}$

Even considering the abundance of atmospheric $\mathrm{N}_{2}$, nitrogen compounds should also be recycled to decrease the huge amounts of energy required to make $\mathrm{N}$ fertilizers and also to decrease eutrophication and other forms of environmental degradation. This may follow the lines presented above, for potassium and phosphate recycling.

Moreover, agriculture can produce its own $\mathrm{N}$ fertilizers, as in the case of soybeans, black beans and some other cultures, thanks to $\mathrm{N}_{2}$ fixation by symbiotic species like Rhizobium. This is one of the keys for the competitiveness of the Brazilian soybeans producers, that do not have to supply $\mathrm{N}$ fertilizers to their plantations. The practice of planting corn right after cropping soybeans (the "safrinha") allows part of the fixed nitrogen to contribute to corn production, also. Dispensing with nitrogen fertilizers in soybean plantations saves many billion US\$ for Brazilian economy, every year.

Other strategies could benefit from phosphate solubilizing bacteria and fungi to improve the phosphorus absorption and commercial products are in early development stage. The development of controlled-release fertilizers, where the nutrients can be supplied as nanoparticles incorporated within hydrogels ${ }^{43}$ or biodegradable polymers is another strategy and commercial products are already available.

Other biotech-based strategy possibility is the integration of tissue culture with controlled release. Plant physiology in their early growth stages is rather different and much more active than in adult plants. This opens room for the development of new technologies that can highly improve nutrient uptake.

\section{CONCLUSIONS}

Increasing biomass production is required to provide food together with energy and raw materials from renewable sources. 
However, increasing biomass production requires fertilizers as plant nutrients that poses new problems due to energy requirements for $\mathrm{N}$ fertilizer production together with the mining problems created to obtain $\mathrm{K}$ and $\mathrm{P}$ ores. Moreover, $\mathrm{K}$ and $\mathrm{P}$ sources are concentrated in a few countries, leaving large agricultural producers strongly dependent on imports. This situation is economically and strategically undesirable, inviting the introduction of alternative methods to supply nutrients to plants. Brazil has a great success in this direction, based on the symbiotic nitrogen fixation in soybeans that saves many billion US\$ every year, but this cannot yet be extended to other plants, beyond Leguminosae. Fertilizer reclaiming, recycling and production from currently non-commercial sources are thus needed to help solving the current and foreseeable problems, in different crops and under different circumstances. Moreover, known environmental and social problems associated to land-use change need to be solved, while avoiding the creation of future ones. Success in this direction depends on the critical use of a large amount of multidisciplinary information including the bio-, social and chemical sciences, making full use of from the current advances in data science. Much new knowledge is needed but efforts should be made to draw research plans considering the broad context and the complexity of agriculture, with its economic, social and environmental impacts.

\section{SUPPLEMENTARY MATERIAL}

Abstract in portuguese (RESUMO) can be freely accessed at http://www.quimicanova.sbq.org.br, in PDF format.

\section{ACKNOWLEGMENTS}

This work was supported by Brazilian agencies MCTIC/CNPq (465452/2014-0) and FAPESP (2014/50906-9) through INCT/ INOMAT (National Institute for Complex Functional Materials). This study was financed in part by the Coordenação de Aperfeiçoamento de Pessoal de Nível Superior - Brasil (CAPES) - Finance Code 001

\section{REFERENCES}

1. Meadows, D. H.; Randers, J.; Meadows, D.; Limits to Growth: The 30Year Update, Earthscan: London, 2004.

2. Galembeck, F.; Pure Appl. Chem. 2018, 90, 109.

3. Arndt, C.; Msangi, S.; Thurlow. J.; Green Energy: Fueling the path to food security in 2016 Global Food Policy Report; International Food Policy Research Institute: Washington, D.C., 2016, chap. 7.

4. Galembeck, F.; de Abreu-Filho, P. P.; Rev. Virt. Quim. 2017, 9, 274.

5. http://www.nytimes.com/1973/11/10/archives/soviet-plant-to-convertoil-to-protein-for-feed-use-of-yeast.htm, accessed October 2019.

6. Goldemberg, J.; Biotechnol. Biofuels 2008, 1, 6.

7. Galembeck, F.; Pardini, V. L.; Quim. Nova 2009, 32, 565.

8. Galembeck, F.; Energy Environ. Sci. 2010, 3, 393.

9. Galembeck, F.; Barbosa, C. A. S.; de Sousa. R. A.; Quim. Nova 2009, 32,571 .

10. Goldemberg, J.; Quim. Nova 2009, 32, 582.

11. National Economy Blueprint, The White House, Washington, 2012. Available from https://obamawhitehouse.archives.gov/administration/ eop/ostp/library/bioeconomy, accessed October 2019.

12. Mills, E.; Franco, J.; Feodoroff, T.; Kay, S.; Vervest, P.; The Bioeconomy, TNI and Hands on the Land: Amsterdam, 2015. Available from https:// www.tni.org/en/publication/the-bioeconomy, accessed October 2019.

13. Galembeck, F.; Macedo, G. A.; Csordas. Y. In Chemicals from sugar cane in Materials for a Sustainable Future; Letcher, T. M., Scott J. L., eds.; RSC: London, 2012, chap. 9.
14. Ferreira, V. F.; da Rocha, D. R.; da Silva, F. de C.; Quim. Nova 2009, 32, 623.

15. Barreiro, E. G.; Bolzani, V. de S.; Quim. Nova 2009, 32, 689.

16. Silva, R.; Haraguchi, S. K.; Muniz, E. C.; Rubira, A. F.; Quim. Nova 2009, 32, 661 .

17. Lapola, D. M.; Martinelli, L. A.; Peres, C. A.; Ometto, J. P. H. B.; Ferreira, M. E.; Nobre, C. A.; Aguiar, A. P. D.; Bustamante, M. M. C.; Cardoso, M. F.; Costa, M. H.; Joly, C. A.; Leite, C. C.; Moutinho, P.; Sampaio, G.; Strassburg, B. B. N.; Vieira, I. C. C.; Nat. Clim. Change 2014, 4, 27.

18. Galford, G. L.; Soares-Filho, B.; Cerri, C. E. P.; Phil. Trans. R. Soc. B. 2013, 368, 20120171.

19. https://cbccoisasdomato.blogspot.com/2013/04/desmatamento-edesenvolvimento.html, accessed October 2019.

20. Carvalho, J. L. N.; Avanzi, C. J.; Silva, M. L. N.; Mello, C. R.; Cerri, C. E. P.; Rev. Bras. Cienc. Solo 2010, 34, 277.

21. Hasanuzzaman, M.; Bhuyan, M. H. M. B.; Nahar, K.; Hossain, M. S.; Mahmud, J. A.; Hossen, M. S.; Masud, A. A. C.; Moumita; Fujita, M.; Agronomy 2018, 8, 31.

22. Visveswaran, R. K. Hypokalemia in Essentials of Nephrology; Visveswaran, R. K., Uthup S., eds.; BI Publications: New Delhi, 2009, p. 257.

23. FAO; World Fertilizer Trends and Outlook to 2020: Summary Report, FAO: Rome, 2017. Available from http://www.fao.org/3/a-i6895e.pdf, accessed October 2019.

24. https://www.yara.com/siteassets/investors/057-reports-and-presentations/ other/2018/fertilizer-industry-handbook-2018-with-notes.pdf/, accessed October 2019.

25. Job, G.; Rüffler, R.; Physical Chemistry from a Different Angle, Springer: Cham, 2016.

26. Bhuiyan, M. I.; Mavinic, D. S.; Beckie R. D.; Environ. Technol. 2007, 28,1015 .

27. Siegfried, R.; ISIS 1963, 54, 247.

28. Liebig, J.; Die organische Chemie in ihrer Anwendung auf Agricultur und Physiologie, Verlag Friedrich Vieweg und Sohn: Braunschweig, 1840.

29. https://investingnews.com/daily/resource-investing/agriculture-investing/ potash-investing/world-class-potash-deposits/, accessed October 2019.

30. http://www.uralkali.com/press_center/press_releases/item41508/, accessed October 2019.

31. http://infopotash.com/en/, accessed October 2019.

32. http://apot.co.th/2015/project.php?id=0000031, accessed October 2019.

33. Reetz Jr., H. F.; Fertilizers and their Efficient Use, IFA: Paris, 2016, p. 23.

34. Van Kauwenbergh, S. J.; World phosphate rock reserves and resources, IFDC: Muscle Shoals, 2010.

35. Edixhoven, J. D.; Gupta, J.; Savenije, H. H. G.; Earth System Dynamics 2014, 5, 491.

36. Scholz, R. W; Wellmer, F.-W.; Earth System Dynamics 2016, 7, 103.

37. European Comission; Third list of Critical Raw Materials, 2017. Available from http://ec.europa.eu/growth/sectors/raw-materials/ specific-interest/critical_en, accessed October 2019.

38. Paltrinieri, L.; Ph.D. Thesis, Delft University of Technology, Netherlands, 2019.

39. Lopez, G. P.; Zeineldin, R.; Piyasena, M. E.; Chemburu S.; US Pat. $8,465,9832013$.

40. Leonardos, O. H.; Fyfe, W. S.; Kronberg, B. I.; Chem. Geol. 1987, 60, 361.

41. Skorina, T.; Allanore, A.; Green Chem. 2015, 17, 2123.

42. Ciceri, D.; de Oliveira, M.; Allanore, A.; Green Chem. 2017, 19, 5187.

43. Cunha, P. L. R. da; Paula, R. C. M. de; Feitosa, J. P. A.; Quim. Nova 2009, 32, 649. 